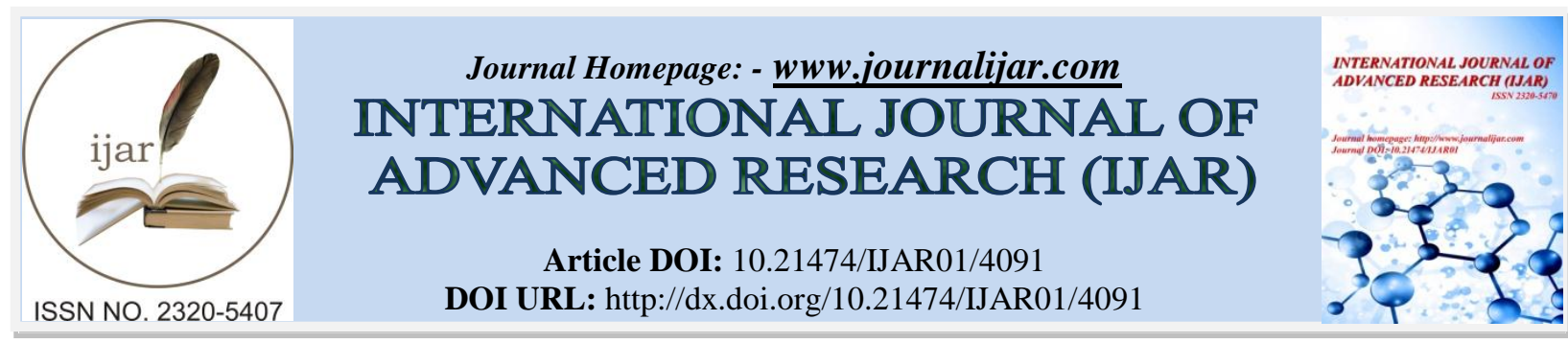

RESEARCH ARTICLE

\title{
INDIAN GOOSEBERRY: A FRUIT WITH CHARISMATIC PROPERTIES AND ITS REJUVENATION METHODOLOGY.
}

\section{"Preeti Choudhary, Parshant Bakshi, Diskit Dolkar and Rafiq Ahmad shah.} Division of Fruit Science,Skuast-J, Chatha.

\section{Manuscript Info}

\section{Abstract}

Manuscript History

Received: 01 March 2017

Final Accepted: 13 April 2017

Published: May 2017

Copy Right, IJAR, 2017,. All rights reserved.

\section{Introduction:-}

The Indian goose berry or aonla is an important minor fruit of arid zone and a crop of commercial significance. Aonla is a highly versatile fruit which is widely used in food preparations. It is cited in literature that aonla posses legendary powers in healing and preventing atherosclerosis and related cardiovascular diseases.

\section{Scientific Classification:-}

Kingdom: Plantae

Division: Angiospermae

Class: Dicotyledonae

Order: Geraniales

Family: Euphorbiaceae

Genus: Emblica

Species: officinalis Geartn

Latin names: Phyllanthus emblica Linn. Emblica officinalis Gaertn.

Habitat: common in tropical and sub tropical India

\section{Ayurvedic Description of Aonla:-}

The aonla fruit has numerous properties that are explored and hence used in Ayurvedic formulations.

Rasa (taste): Fruits has five tastes: sweet, bitter, pungent, sour and astringent out of which last two are more prominent.

Veerya (nature): cooling

Vipaka (taste developed through digestion): sweet

Guna (qualities): light, dry

Doshas (effect on humors): quietens all three doshas: vata, kapha, pitta, and is especially effective for pitta

\section{Chemical Constituents of Aonla:-}

One of the richest source of Vitamin $\mathrm{C}$ and its vitamin value increases after the extraction of the juice. The fruits bark and leaves are rich in tannins. The seed of the Indian gooseberry contains a fixed oil, phosphatides, and an essential oil. 


\section{Cultural Importance:-}

Aonla has been regarded as the sacred tree in India. It is worshipped as mother earth and it is believed to nurture humankind because the fruits are very nourishing. It stimulates spiritual purity. Kartik Mahatma and Vat kaumuddi order the worship of this tree its fruits and flowers are used in worship.

\section{Medicinal Properties of Aonla:-}

Indian gooseberry is a valuable ingredient of various medicines in India from time immemorial. Aonla fruits are acrid, cooling, refrigerant, astringent, carminative, stomachic, diuretic and laxative. The fruits are useful in vitiated conditions of Tridosahas, diabetes, cough, asthma, bronchitis, cephalalgia, ophthalmopathy, dyspepsia, colic, flatulence, hyperacidity, peptic ulcer, erysipelas, skin diseases, leprosy, haematogenesis, inflammations, anaemia, emaciation, hepatopathy, jaundice, strangury, diarrhoea, dysentery, haemorrhages, leucorrhoea, menorrhagia, cardiac disorders, intermittent fevers

\section{Aperient:-}

The green fruits are made into pickles and preserves to stimulate the appetite.

\section{Antioxidant:-}

Aonla possesses strong antioxidant activity which has been revealed by number of scientists worldwide. Aonla is a potent scavenger of free radicals. It also contain Superoxide dismutase activity.

\section{Aphrodisiac:-}

Aonla is considered to be one of the strongest rejuvenative herbs in Ayurvedic medicine. It is the primary ingredient used in one of the renowned Ayurvedic herbal formulae, called Chayavanprasha which has great respect as a tonic.

\section{Chelating agent:-}

Aonla was shown to reduce UV induced erythema and had excellent free-radical quenching ability, chelating ability to iron and copper. In the present scenario photo aging of the skin is a complex biologic process affecting various layers of the skin.

\section{Dental problems:-}

The roots of Emblica officinalis are useful in dental problems.

\section{Diabetes:-}

The fruits are used in the treatment of diabetes. Decoctions of the leaves and seeds are used in the treatment of diabetes mellitus.

\section{Diarrhoea:-}

It is used medicinally for the treatment of diarrhoea.

\section{Scurvy:-}

Anti-ascorbutic virtues have been attributed to the fruits, which are known as the Emblic Myrobalans

\section{Skin whitening:-}

Emblica officinalis fruits are known to have skin lightening properties and depigment the skin.

\section{Nutritive Value Of Aonla:-}

Aonla has been called the best of the Ayurvedic rejuvenating herb, because through the natural balance of tastes (sweet, sour, pungent, bitter and astringent) all in one fruit. Aonla fruit is probably the richest known natural source of vitamin C. The fruit juice contains nearly 20 times as much vitamin $\mathrm{C}$ as orange juice and a single fruit is equal to anti scorbutic value to one or two oranges. It also contains minerals and amino acids such as calcium, phosphorus, iron, niacin, carotene, thiamine and riboflavin. Indian Gooseberry has also been found to be low in saturated fat, sodium and cholesterol making it good for health. 


\section{Pests And Disease:-}

Caterpillar, leaf rolling caterpillar, bark eating caterpillar, mealy bug etc. are the main pests. Ring rust, fruit rot, leaf rust etc are the diseases affected aonla. Plant protection measures should be followed as recommended by the horticulture expert.

As a control measure injection of endosulphon $0.05 \%$ or monocrotophos $0.03 \%$ in holes and plugging with mud is effective in protecting the tree against bark eating caterpillars. Spraying of indofil M-45@0.3\% twice first in early September and second after 15 days after first application controls the spread of rust.

\section{Need For Rejuvenation:-}

It is also commonly observed that living organism loses its efficiency to perform various functions after some period of time (vary from species to species). Similarly in fruit plants also, there is a decline both in quality and quantity of produce after some period of time due to which orcharding becomes economically nonviable and non-remunerative. In the recent years declining productivity of old and dense orchards existing in abundance has become a matter of serious concern for the orchardists, traders as well as scientists. To overcome this problem research effort were initiated to standardize a technology for restoring the production potential of existing plantations by a technique called Rejuvenation.

Now the question arises why the old orchards need to be rejuvenated and the answer is:

The old fruit orchards need to be rejuvenated as they show decline in yield and quality of produce which may be attributed to any one of the following factors:

- Reduction in the photosynthetic surface area.

- Non availability of productive shoots.

- Increased incidence of insect pests and diseases.

- Less penetration of sunlight due to overcrowding of branches as a result of which the interior areas of the tree do not develop proper colour of fruit

- The slow cause of declination in productivity and quality is due to poor orchard management and overage trees.

\section{Technique For Rejuvenating The Senile Orchards:-}

Orchard loses their productivity beyond 25 years due to biotic stresses and abiotic stresses. The rejuvenation technology involves the heading back of exhausted trees showing marked decline in annual production and quality of produce to the extent of 1.0 to 1.5 meter height above the ground level during May-June or December-February with the objective of facilitating production of new shoots from below the cut point and allow the development of fresh canopy of healthy shoots. Primary branches 2-4 well spaced ones should be allowed at about one meter height. Regular pruning consists of removal of unwanted, unhealthy, diseased, overlapping and damaged shoots. The newly emerging shoots are allowed to grow up to $40-50 \mathrm{~cm}$ length and then further pruned for emergence of multiple shoots below the pruning point to modify the tree structure and maintain canopy size. Profusely emerging shoots in the inner canopy are also pruned out to promote branching. The multiple shoots developed as a result of second pruning are capable of producing flower buds.

\section{Economical Point Related To Aonla Rejuvenation:-}

- Sale of wood obtained after heading back operation can generate income.

- Interspaces are used to grow suitable inter crops which generate additional income for the farmers.

Important Cultivars:-

Few important varieties suitable for growing in Jammu sub tropics are

- Banarsi

- NA-4

- NA-5

- NA-6

- NA-7

- NA-10

- $\quad$ Laxmi 52 


\section{Propagation Methods:-}

Budding: out of various methods of propagation, budding has been found to be the best method. Patch budding and shield budding are the commercial methods of aonla propagation.

\section{Grafting:-}

Another widely used method to raise aonla is grafting. Generally graft which is used is of superior quality.

\section{Rootstock:-}

One year old seedling developed from desi aonla seed is used as rootstock. Mature aonla fruits are obtained and their seeds are extracted, further seeds are sown in raised beds and then transplanted in separate beds for subsequent budding.

\section{Present status:-}

India is the largest producer of aonla after Sri lanka, Cuba, USA, Iran, Iraq etc. Aonla growing states in India are Jammu\& Kashmir, Haryana, Himachal Pradesh, Uttar Pradesh, Rajasthan, Maharashtra and Tamil Nadu. In Jammu and Kashmir aonla is cultivated on an area of 993.83 ha with a production of about 1065.24MT (2014-15).

\section{Cost Of Production:-}

Cost of production per hectare involves total cost of labour, intercultural operations, shoot thinning, irrigation, manuring and fertilization, plant protection measures etc. The material cost involves cost of manures, fertilizers, insecticides, fungicides etc

\section{Conclusion:-}

Aonla thrives well under drought conditions, having long period of life, low investment, minimum care and its medicinal value can make aonla farming a very profitable business. 